Int. J. Electrochem. Sci., 11 (2016) $6244-6255$

\title{
Sensitive Voltammetric Determination of Paracetamol on Poly(4-Aminobenzene Sulfonic Acid) Modified Glassy Carbon Electrode
}

\author{
Selehattin Yilmaz ${ }^{1}$, Zeynep Bas ${ }^{1}$, Murat Sadikoglu, ${ }^{2, *}$, Sultan Yagmur ${ }^{1}$, Gulsen Saglikoglu ${ }^{1}$ \\ ${ }^{1}$ Canakkale Onsekiz Mart University, Faculty of Science and Arts, Department of Chemistry, 17020, \\ Canakkale, Turkey \\ ${ }^{2}$ Gaziosmanpasa University, Faculty of Education, Department of Science Education, 60240, Tokat, \\ Turkey \\ *E-mail: murat.sadikoglu@yahoo.com
}

doi: $10.20964 / 2016.07 .74$

Received: 12 April 2016 / Accepted: 15 May 2016 / Published: 4 June 2016

\begin{abstract}
A poly (4-aminobenzene sulfonic acid) (4-ABSA) modified glassy carbon electrode (GCE) was prepared for the quantitative determination of paracetamol (PCT). The 4-ABSA-modified GCE was prepared by electrochemical polymerization method in phosphate buffer solution (PBS) (pH 7.0). The polymer film-modified electrode has high catalytic ability for electrooxidation of PCT, which appeared at $\mathrm{pH}$ range of 5-8 by cyclic voltammetry $(\mathrm{CV})$ and differential pulse voltammetry (DPV) techniques. The best results for the determination of PCT were obtained by DPV in PBS (pH 7.00). Calibration curve was obtained in the PCT concentration range of $6 \times 10^{-7}$ to $9 \times 10^{-6} \mathrm{~mol} \mathrm{~L}^{-1}$ by DPV. Limit of detection (LOD) and quantification (LOQ) were found as $9.33 \times 10^{-8} \mathrm{~mol} \mathrm{~L}^{-1}$ and $3.10 \times 10^{-7}$ mol L ${ }^{-1}$, respectively. The results of experiments indicated that modified electrode have good stability, sensitivity and reproducibility for at least one month if stored dry in air.
\end{abstract}

Keywords: Poly(4-Aminobenzene Sulfonic Acid), modified-glassy carbon electrode, electropolymerization, electrocatalytic oxidation, paracetamol, determination, voltammetry.

\section{$\underline{\text { FULL TEXT }}$}

(C) 2016 The Authors. Published by ESG (www.electrochemsci.org). This article is an open access article distributed under the terms and conditions of the Creative Commons Attribution license (http://creativecommons.org/licenses/by/4.0/). 